$\xi=2$

\title{
Peripheral giant cell granuloma: a case report
}

\author{
Saad Shahnawaz Ahmed ${ }^{1}$, Hira Zaman ${ }^{2}$, Fahad Bin Abrar ${ }^{3}$, Sadia Khalid ${ }^{4}$ \\ ${ }^{I}$ BDS, House Officer in Dental Department, Shaheed Zulfiqar Ali Bhutto Medical University, (PIMS), Islamabad, Pakistan \\ ${ }^{2}$ BDS, PG resident (MDS operative dentistry) Shaheed Zulfiqar Ali Bhutto Medical University, (PIMS), Islamabad, Pakistan \\ ${ }^{3}$ BDS, House Officer in Surgery Department, Islamabad Medical and Dental College (IMDC), Islamabad, Pakistan \\ ${ }^{4}$ BDS, Medical Officer in Shifa International Hospital, Islamabad, Pakistan \\ *Corresponding author E-mail: saadahmed552@hotmail.com
}

\begin{abstract}
Peripheral giant cell granuloma (PGCG) is a common benign gingival lesion in the oral cavity of unknown origin, believed to be stimulated by local irritation or chronic trauma. It is also known as giant cell epulis, giant cell reparative granuloma, or giant-cell hyperplasia, presenting as purplish-red soft tissue nodule clinically and histologically consisting of multinucleated giant cells in a background of mononuclear stromal cells and extravasated red blood cells. This case report describes a 40 year old male previously reported with peripheral giant cell granuloma 2 years back which on excision reoccurred after 3-4 months and persistently growing since then. The gingival lesion between his maxillary central incisors was excised and the Biopsy specimen sent in 10\% formalin to histopathological lab and was diagnosed as PGCG. There was good healing of tissue of the surgical site during the 9 months follow-up.
\end{abstract}

Keywords: Anesthesia; Excisional Biopsy; Giant Cell; Granuloma; Lesion

\section{Introduction}

The peripheral giant cell granuloma (PGCG) is a non-neoplastic, usually asymptomatic and reactive hyperplastic lesion in nature accounting 7\% of all benign tumors of the jaw (Pour Mah et al 2008), with slightly high predilection in females than males. The exuberant mass lesion is soft, sessile or pediculate, clinically similar to that of pyogenic granuloma (Ga'ndara JM et al.2002), deep red or purplish in color, developing on gingival mucosa or alveolar ridge (Neville B.W. et al. 2004).Hence radiographic examination may or may not show significant findings.

It is suspected to occur due to local trauma or irritation such as tooth extraction, inadequate dental restorations, ill-fitting dentures, food impaction, plaque and calculus (Aslan M et al. 2006, Etoz OA et al. 2010).Although it has also been reported to be associated with dental implants, little information in the literature is available regarding the prevalence of this reactive lesion. It may develop due to mechanical or biological irritation, inappropriate implant placement or poor oral hygiene maintained post operatively (D. G. Olmedo et al. 2010). Another concept is that the giant cells present in the lesion may be derived from deciduous teeth hence they may be found in young patients with deciduous teeth or patients with retained deciduous teeth (Pogrel AM. et al. 2012)

Usually these lesions tend to increase in size, varying from 0.5 to $2 \mathrm{~cm}$ in diameter but can be greater. PGCG is locally destructive and occasionally shows an aggressive biologic behavior and recurrence is approximately $10 \%$ (Motamedi, M.H.K et al. 2007) In some patients PGCG may cause resorption of the alveolar ridge as cupping resorption or superficial crestal bone destruction. Diagnosis can be done with histopathological examination of the excised specimen. Treatment is done by complete excision of the lesion with normal tissue involvement and debridement of underlying soft tissue or bone, to prevent the rare chance of recurrence.

\section{Case report}

A 40 year old male patient came to dental department with a complain of red, painless swelling in his upper anterior region between the central incisors(Fig.1).The swelling had been gradually increasing in size for the past 2 months causing his central incisors to be mobile and deviate from each other. Past history revealed occurrence of a lesion 2 years back and excision biopsy was done in a tertiary care hospital, which was diagnosed as PGCG and recurred after 3-4 months of the initial treatment. The medical history of the patient was not significant and the patient was healthy.

On examination a large, soft, non-mobile lesion was seen present between the maxillary central incisors. The central incisors were discolored due to necrosis of pulp and were also asymptomatic on percussion and vitality test. After clinical examination and radiographic evaluation, surgical excision of the lesion along with extraction of the maxillary central incisors was planned under local anesthesia. The patient was thoroughly explained the procedure and consent taken.

Before procedure patient was made to rinse with $0.2 \%$ Chlorhexidine Gluconate mouthwash ( Enziclor mouthwash).The surgical site was infiltrated with Lignocaine(elite pharma) $2 \%$ solution of 1:100000 epinephrine labially and palatally.Markings of the incison line were made with indelible pencil including $1 \mathrm{~mm}$ of normal tissue.Complete anesthesia of the lesion site and maxillary central incisors was obtained.The coronal gingival margin around the maxillary central incisors was detached using periosteal elevator and the mobile teeth were gently extracted using presidental standard upper anterior forcep(triangles).A smooth continous elliptical incision with no. 15 blade was made at the marked line around the lesion and the lesion excised(Fig.2).Adequate continous irrigation was maintained during the procedure.Curretage 
with spoon excavator (triangles) of the granulation tissue and underlying alveolar bone was done.Using a bone file (triangles) the alveolar bone was made smooth inculding the extracted alveolar sockets.Irrigation of the surgical site was done and 4-0 silk sutures were placed to re-aproximate the gingival tissue(Fig.3).The specimen obtained was sent to histopathology lab for diagnosis (Fig.4).The wound was covered with Zincoxide Eugenol dressing (septodont) and patient recalled after 7 days for removal of sutures with follow-up (Fig.5).Antibiotic coverage with amoxicillin (cap.amoxil 500mg) TDS, metronidazole (tab.flagyl 400mg) BD and analgesic ibuprofen (tab.brufen $400 \mathrm{mg}$ ) BD for 5 days was prescribed.

A follow up of 9 months was done with good healing of the surgical site and with no recurrence noticed.

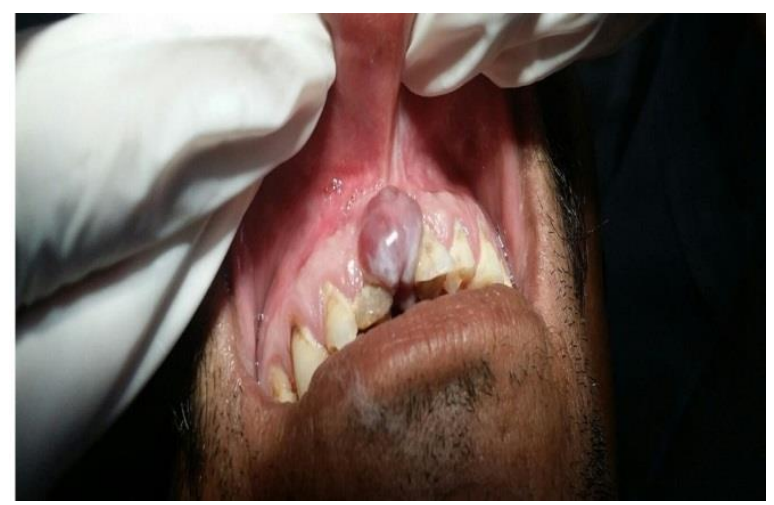

Fig. 1: Pre-Operative Picture of the Lesion.

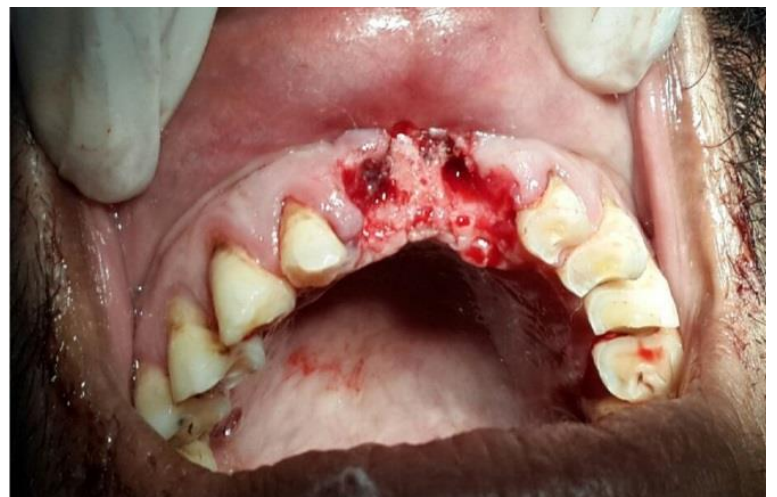

Fig. 2: An Intraoperative Picture after Excision of Lesion and Extraction of Maxillary Central Incisors.

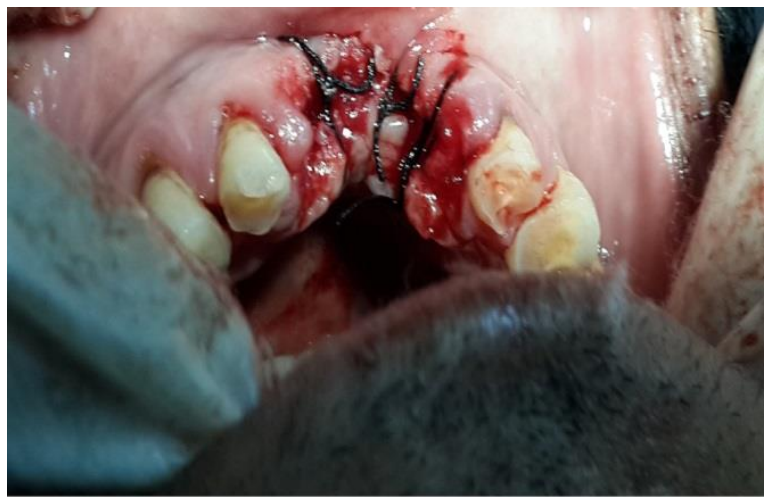

Fig. 3: Showing 4/0 Silk Sutures Being Placed after Excision and Debridement.

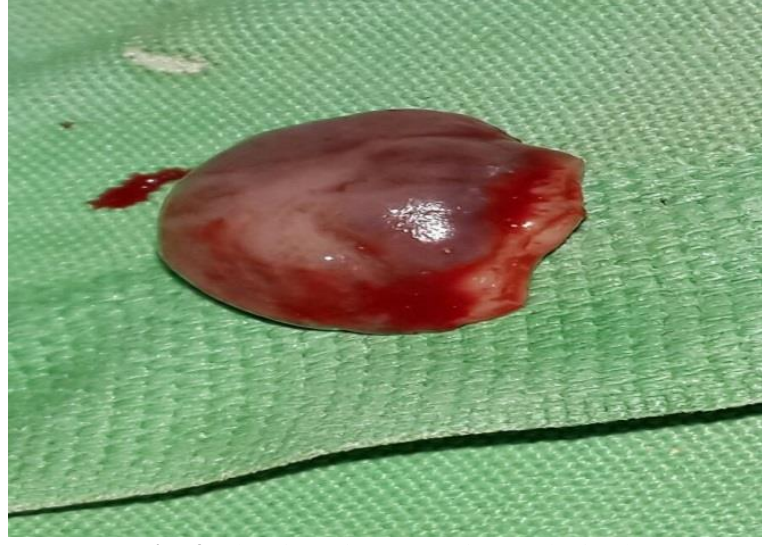

Fig. 4: Showing Biopsy Specimen Obtained.

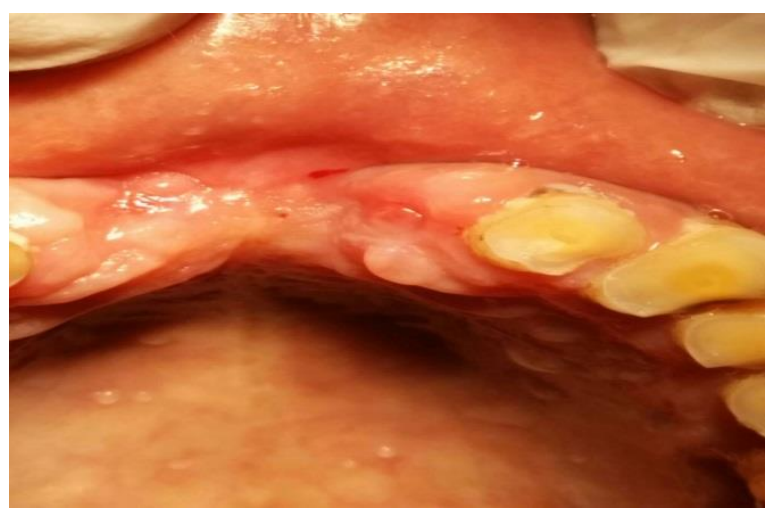

Fig. 5: Showing Post-Operative Healing of the Surgical Site after One Week.

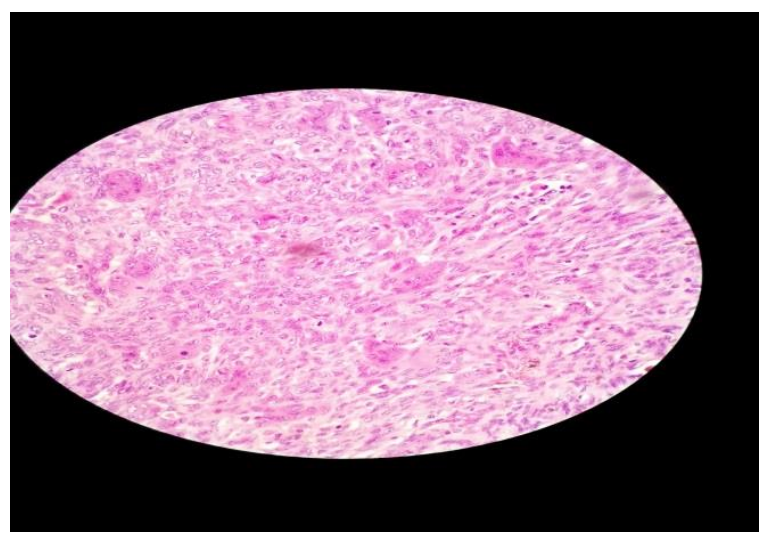

Fig. 6: Histopathological Image of Pgcg.

\section{Discussion}

Peripheral giant cell granulomas are benign, rare tumors originating from mucoperiosteum or gingival soft tissue of alveolar bone in the oral cavity (Gandara RJM et al. 2002, Etoz OA et al. 2010).Its exact etiology is unknown but it is believed to occur due to local trauma and chronic irritation .It presents as smooth ,reddish or purple colored lesion varying from 0.5 to 1.5 $\mathrm{cm}$ in size but may also be greater than $2 \mathrm{~cm}$. The consistency of the lesion can be from soft to firm which depends upon the age of lesion as collagen fibers increase with age making the lesion more firm (Muratakgül H. et al.2004). These lesions can grow rapidly in children reaching to significant sizes and may cause interference with normal teeth eruption or bone loss leading to tooth mobility (Kumar A et al.2014).The presenting case report also explains about the patient with soft and painless PGCG which recurred after 3-4 months of excision resulting in mobility of adjacent teeth. Bleeding from the lesion may occur on secondary trauma. PGCGs are more common in females than males in $4^{\text {th }}$ to $6^{\text {th }}$ decade of life (Grand E. et al 2008). Elevation of certain hormones such as estrogens, progesterone (Pen $\sim$ arrocha-Diago.M et al. 2012), para- 
thyroid hormone (PTH) and calcium levels (Pirih, F. et al 2015) may play a role in the development of PGCG. It has also been seen in patients with hyperparathyroidism since it causes hypercalcemia (Fraser, W.D. 2009).

The microscopic appearance of lesion is characterized by a nonencapsulated, highly cellular mass with abundant multinucleated giant cells and neutrophils overlying a mesenchymal tissue composed of plump, ovoid-shaped nuclei with abundant multinucleated giant cells and extravasated erythrocytes (Pirih, F. et al 2015). Osteoblasts, phagocytes, endothelial cells, and spindle cells are thought to be responsible for giant cell proliferation (Mannem S. et al 2012), hence may also cause resorption of the underlying bone. A similar pattern was seen in the histopathological and microscopic examination of the presenting patient.

The differential diagnosis of peripheral giant cell granuloma includes pyogenic granuloma, fibrous epulis, peripheral ossifying fibroma, inflammatory fibrous hyperplasia and peripheral odontogenic fibroma. All of these can have identical clinical or radiographic findings (Ragezi JA et al.2003).Treatment of PGCG is done by complete excision involving the underlying tissue, if the excision is superficial re-growth may occur (Shadman $\mathrm{N}$ et al 2009), hence it has also been suggested to extract the teeth whose periosteum have been involved which may cause the lesion to reoccur (Chaparro-Avendano AV et al 2005).As the patient in this case report demonstrates whose involved teeth with PGCG were not extracted in his previous excisional treatment and had reoccurred.

\section{Conclusion}

PGCG is an often encountered in dental practice. Proper diagnosis, histopathological examination and treatment are essential in preventing aggressive therapy, periodontal loss and recurrence of the lesion. By early diagnosis, thorough knowledge, radiographic evaluation and histopathological identification we can achieve reduction in recurrence and provide conservative management of the surrounding hard tissues to the patient.

\section{Acknowledgements}

I acknowledge my senior doctors specially Dr. Sadia Khalid and my colleagues for guidance and help.

\section{References}

[1] Pour MAH, Rad M, Mojtahedi A. A Survey of Soft tissue TumorLike Lesions of Oral Cavity: A Clinicopathological Study. Iran J Pathol. 2008; 3: 81-7.

[2] Neville B.W., Damm D.D., Allen C.M. and Bouquot J.E.Oral and Maxillofacial Pathology, Pennysylvania: W B Saunders Company, 2004; 449-50.

[3] Aslan M, Kaya GS, Day E, Demirci E. A Peripheral giant cell granuloma in early age (case report). Ataturk Univ Dis Hek Fak Derg 2006; 16(3):61-4

[4] Etoz OA, Demirbas AE, Bulbul M, Akay E. The peripheral giant cell granuloma in edentulous patients. Report of three unique cases. Eur J Dent. 2010; 4:329-33.

[5] D. G. Olmedo, M. L. Paparella, D. Brandizzi, and R. L.Cabrini. Reactive lesions of peri-implant mucosa associated with titanium dental implants: a report of 2 cases.Int J Oral Maxillofac Surg.2010 39(5): 503-7. http://dx.doi.org/10.1016/j.ijom.2009.11.007.

[6] I. Dojcinovic, M. Richter, and T. Lombardi. Occurrence of a pyogenic granuloma in relation to a dental implant. J. Oral Maxillofac. $\begin{array}{llll}\text { Surg. } & 2010 ; & 68 & \text { (8):1874-6. }\end{array}$ http://dx.doi.org/10.1016/j.joms.2009.06.015.

[7] Ga'ndara JM, Pacheco JL, Ga'ndara P, et al. Granuloma perife'rico de ce'lulas gigantes. Revisio'n de 13 casos clı'nicos. Med Oral Med Oral Patol Oral Cir Bucal. 2002; 7:254-9.

[8] Motamedi, M.H.K., Eshghyar, N., Jafari, S.M., Lassemi, E., Navi, F., et al. (2007) Peripheral and Central Giant Cell Granulomas of the Jaws: A Demographic Study. Oral Surgery, Oral Medicine, Ora
Pathology, Oral Radiology, and Endodontology, 103, e39-e43. http://dx.doi.org/10.1016/j.tripleo.2006.12.022.

[9] Pogrel AM. The diagnosis and management of giant cell lesions of the jaws. Ann Maxillofac Surg 2012; 2:102-6. http://dx.doi.org/10.4103/2231-0746.101325.

[10] Gandara RJM, Carneiro PM, Gandara VP, Carrion BA, Garcia GA, Grana P, Martin. Peripheral giant cell granuloma. Review of 13 cases. Med Oral. 2002; 7(4): 254-59.

[11] Muratakgül H., Güngrmü M., and Harorli A. Peripheral giant cell granuloma: A clinical and radiological study.Fundamentals of Radiology and Radiodiagnostics in Dentistry, 2004; 16: 59-63 http://dx.doi.org/10.1163/156856904322858710.

[12] Kumar A, Singh VP and Shah P. Peripheral Giant Cell Granuloma: a Case Report. J Dent App. 2014; 1 (3): 43-5.

[13] Ragezi JA, Sciubba JJ, Jordan RC. Oral pathology: Clinicopathological considerations. 4th ed. Philadelphia: W B Saunders. 2003:115-6.

[14] Pen arrocha-Diago.M , Cervera-Ballester.j , Maestre-Ferrı'n.L Pen arrocha-Oltra.D. Peripheral Giant Cell Granuloma Associated With Dental Implants: Clinical Case and Literature Review.journal or oral implantology. 2012;38:(1):527-32

[15] Pirih, F., Barroso, A.D., Tatarakis, N., Cordell, K., McCauley, L. and Edwards, P. A Case Report of a Peripheral Giant Cell Granuloma in a Patient on Forteo. Open Journal of Stomatology. 2015; 5 , 147-51 http://dx.doi.org/10.4236/ojst.2015.56020.

[16] Fraser, W.D. (2009) Hyperparathyroidism. The Lancet, 374, 145-58. http://dx.doi.org/10.1016/S0140-6736(09)60507-9.

[17] Grand E, Burgener E, Samson J, Lombardi T. Post-traumatic development of a peripheral giant cell granuloma in a child. Dent Traumatol. 2008; 24:124-6. http://dx.doi.org/10.1111/j.16009657.2006.00504.x.

[18] Mannem S, Chava VK. Management of an unusual peripheral giant cell granuloma: A diagnostic dilemma. Contemp Clin Dent. 2012; 3:93-6 http://dx.doi.org/10.4103/0976-237X.94556.

[19] Shadman N, Ebrahimi SF, Jafari S, Eslami M. Peripheral giant cell granuloma: A review of 123 cases. Dent Res J han) .2009;6:47-50

[20] Chaparro-Avendano AV, Berini-Aytes L, Gay-Escoda C. Peripheral giant cell granuloma. A report of five cases and review of the literature. Med Oral Patol Oral Cir Bucal. 2005; 10 (1):53-7. [PubMed]. 